\title{
Inventory of Hydro-Ameliorative Works in the Area of Aghireșu, Cluj County in Order to Establish Measures and Works for Rehabilitation
}

\author{
Marius SĂBĂDAȘ ${ }^{1 *}$, Marcel DÎRJA ${ }^{1}$, Mihai VOEVOD ${ }^{1}$, Iulia GLIGA ${ }^{1}$, Maria MOLDOVAN ${ }^{1}$ \\ ${ }^{1}$ Department of Land Measurement and Exact Sciences, University of Agriculture Sciences and \\ Veterinary Medicine Cluj-Napoca, 3-5 Mănăştur Street, 400372, Cluj-Napoca, Romania \\ * corresponding author: marius.sabadas@usamvcluj.ro
}

Bulletin UASVM Horticulture 75(2) / 2018

Print ISSN 1843-5262, Electronic ISSN 1843-536X

DOI:10.15835/buasvmcn-hort: 2018.0008

\begin{abstract}
The objective of the research was to identify agricultural hydro-ameliorative works located in Aghireşu, the area covered by the Nadăş hydrographic basin considering for scientific purpose and economic importance. The studied area is part of the south-west of Someş Plateau and is important for the local community and also for neighboring areas. The influence of the environmental factors, on the basic conditions, for the cultivation and the development of the agricultural crops has a very important role. Land reclamation works applied on agricultural land in the hydrographic basin from the studied area have been over the years measures that have helped to remove the negative consequences on agriculture. Excess of humidity manifested in different forms had a particular impact onagrari soil fertility and hydro-ameliorative works have determined use of abandoned land.
\end{abstract}

Keywords: environment, hydrographic basin, landscaping

\section{Introduction}

The environment must be protected as much as possible and in order to ensure the health of present and future generations, land reclamation works are needed for agricultural area, which give them especial qualities by making them fertile for as long as possible, thus ensuring the production of quality and sufficient food. Rural space has diversified with the evolution of technology but it remained the area where agricultural production is predominant, so much needed for the population's nutrition. Agricultural activities are dependent on land improvement activities and in their absence the potential ratio could not be highlighted. Lindsay et al., 2009, in their research have studied soil degradation, biodiversity for activities to combat desertification in southern Romania, to allow the development of sustainable environmental solutions. Sustainable development of agriculture must predict measures to protect the environment through land improvements represented by works to combat soil erosion and floods, irrigation systems, drainage works, check-dams and regulating water courses and also forestry plantations (Dîrja et al., 2011).

Land reclamation works have a high economic significance and for a long period of time through their radical intervention on natural ecosystems by increasing the agricultural production capacity (Constantin and Maracineanu, 2005). Data subject to this study on hydro-land reclamation works in the Nadăs hydrographic basin were collected from the archives of Aghireșu, Cluj County as well as from the National Agency for Land Improvements (ANIF), Territorial Subsidiary Tisa - Someș. The small distance from the residence, Cluj County, that is $40 \mathrm{~km}$, is an extra argument for the importance of investments in these landscapes that result in larger agricultural productivity and also protect the environment, thus being also economically efficient, for present and future generations regarding sustainability. Researches in the field of 

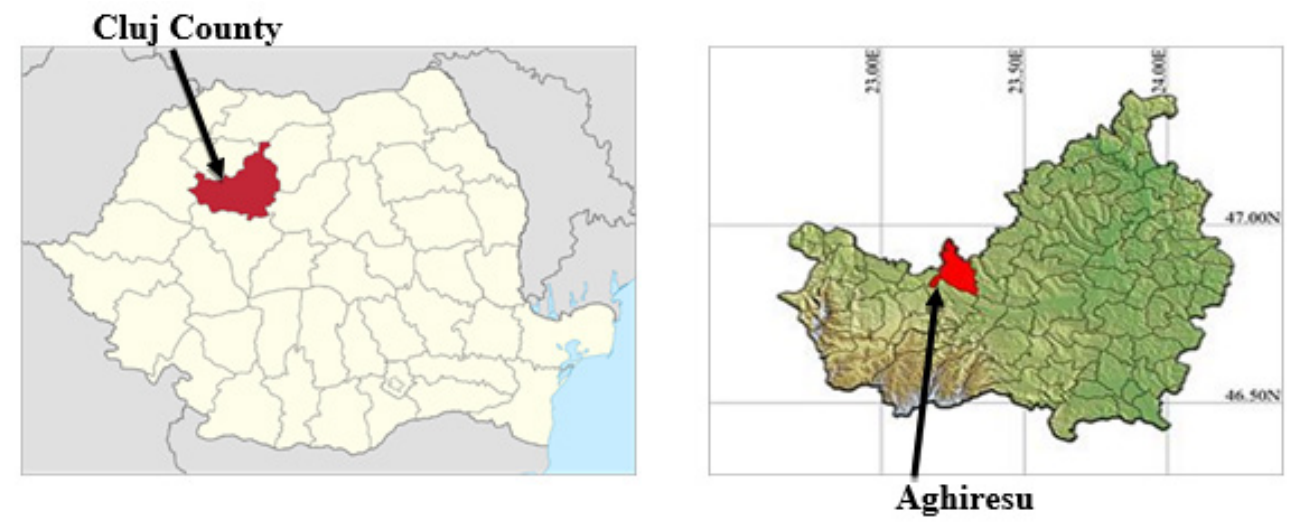

Figure 1. The studied area by locating it on the map of Romania Cluj county and Aghiresu village

Somesul Mic hydrographic basin

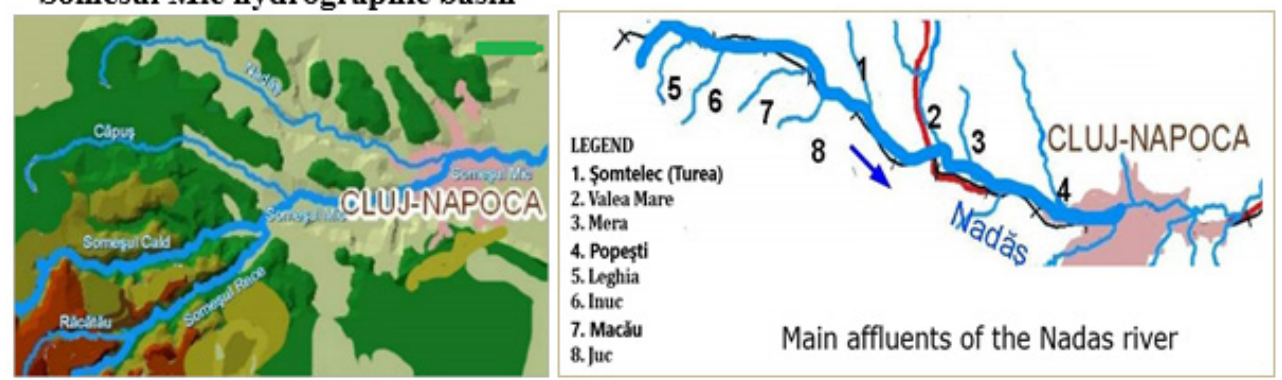

Figure 2. Somesul Mic River with affluents and representation sub-basin Nadas with affluents

environmental protection and land use were made by researchers like Cowie et al., 2007.

\section{Materials and methods}

The case-study was in Nadas river basin, which is located in the Somes-Tisa hydrographic area, the Somes sub-basin and is part of the 403 water courses officially registered in the $\mathrm{N}-\mathrm{V}$ part of Romania, Cluj county (Figure 1 and 2). In this research have been inventoried land reclamation works according to data collected from ANIF, which have been found rehabilitated in studied area during the period 1987-2017.

The research aims has been oriented to identify the land reclamation works in the are of Nadas watershed sub-basin, in order to establish measures and works for rehabilitation, given the high costs involved with such works, but taking into account their high importance for agricultural land use, significantly economic agricultural production and for environmental protection (Dîrja and Sălăgean, 2015).

The research and specific analysis for rehabilitation of land works, took place in an area where over the years coal and sand extraction took place, the mining exploitations being a specific activity of the area. The study aimed to draw attention to the lack of land-use works over a longer period of time in an area with real potential for agricultural production.

The Figure 2 displays Somesul Mic River with affluents, and sub-Basin Nadas with affluents: Somtelec (Turea), Valea Mare, Mera, Popesti, Leghia, Inuc, Macau and Juc.

The purpose of the research was to identify what can be rehabilitated and what can be made in future for an area with real agricultural importance taking into consideration rural sustainable development. This was clearly demonstrated at international level about importance of land reclamation and agricultural production. The proposal will be presented as practical results of the study.

\section{Results and discussions}

The works carried out for identification of land reclamation have brought into attention long period of time when nothing, or too few activities, have been done, the motive being, missing financial support. Through the collected data the study brought to attention the lack of specific specialized human resources for involvement in the land 
Table 1. Land reclamation works according to ANIF evidence, Nadas Sub-basin

\begin{tabular}{lc}
\hline \multicolumn{1}{c}{ Land reclamation works } & Measurement units \\
\hline Total area of the Sub-basin & $2832 \mathrm{ha}$ \\
\hline Exploitation roads & $25,4 \mathrm{~km}$ \\
\hline Drainage network & $29,9 \mathrm{~km}$ \\
\hline Waterways & $49 \mathrm{pcs}$ \\
\hline Collection facility & $12 \mathrm{pcs}$ \\
\hline Collector channels, flow bridge & $24 \mathrm{~km}$ \\
\hline Falls and decks & $17 \mathrm{pcs}$ \\
\hline Tubular bridge(600/800/1000mm) & $35 \mathrm{pcs}$ \\
\hline Prefabricated bridges & $2 \mathrm{pcs}$ \\
\hline Stone masonry dams & $3 \mathrm{pcs}$ \\
\hline Water thresholds & $15 \mathrm{pcs}$ \\
\hline Fence vegetation on the slope & $74 \mathrm{pcs}$ \\
\hline Valley bed consolidated & $1 \mathrm{pcs}$ \\
\hline
\end{tabular}

improvement activities. From the relief point of view, the research was carried out in the area of Cluj Hills, at elevation between $400-500 \mathrm{~m}$, in the south-western part of Somesan Plateau between the interconnected area and the premontonic area of the Apuseni Mountains, which also includes the Capus-Nadas hills area. The affluents of Nadas valley have lengths of several kilometers with low depths, forming in the sub-watersheds the depression areas in which they are located, several localities that are part of Aghiresu village. The meadow of Nadas valley has a well developed extended terrace and affluent valleys, located at an altitude of $425-450 \mathrm{~m}$, with alluviums with thickness between 1.5-3m (Rus, 2015). The width of the terrace is between $50-60 \mathrm{~m}$ to $80 \mathrm{~m}$ in areas shedding of affluents.

Table 1 presents the results of Inventory of hydroameliorative works in Sub-basin Nadas, CES Măcău-Inuc, according to ANIF evidence. From the list of works for land reclamation, in the landscaped area, it can be seen that the majority were executed for combating excess humidity and floods protection.

In the above table can be seen land reclamation works for drainage and combating soil erosion realized in 2014 (Tab. 2) through the project of ANIF when was made reception for the work „Regularization of leakage on the slopes and prevention of landslides in the Someş Mic Hydrographic Basin, Inuc valey, Cluj county", investment value 238.961,201Euro.
In the area where the research was carried out land reclamation works were identified, which through their effect contributed to the protection and improvement of the environment. Through these works of land reclamation also the purpose was the valorification of the production capacity of land, making use of large unproductive land, very useful after projects implementation for obtaining large areas with crops. Land improvement arrangements that have a degree of technicality based on implementation projects on the territory of Romania have been recorded since the 20th century, even if for these types of works, more historical evidence has been found. Over the time, according existing evidence the Romanian state has assumed the right as well as the responsibility acording law, for the management and exploitation of the land reclamation activities (Constantin and Maracineanu, 2005). The importance of specific land reclamation for the studied area resulted from the large area of agricultural crops recorded years ago according to archive evidence and also from the significant areas of agricultural land that could be exploited in the Nadas river sub-basin area. In order to protect the villages and to avoid erosion, especially during periods of excess rainfall and also due to the good quality of the land according to the evidences of the Agricultural Directorate of the Cluj County, most of the land reclamation works were executed in the Inuc-Macau area (http://www.anif.ro). 
Table 2. Land reclamation works CES Măcău-Inuc, construction completed in 2014 trough ANIF

\begin{tabular}{lc}
\hline & Inuc valley \\
\hline Land reclamation works & Measurement units \\
\hline Resharping exploitation roads & $3726 \mathrm{~m}^{3}$ \\
\hline Consolidation of agricultural roads with stone & $1200 \mathrm{~m}^{3}$ \\
\hline Marginal canal & $0,5 \mathrm{~km}$ \\
\hline Tubular stacks & $1 \mathrm{pcs}$ \\
\hline Drainage channels $(800 \mathrm{~mm}),(1000 \mathrm{~mm})$ & $2,3 \mathrm{~km}$ \\
\hline Prefabricated bridges & $2 \mathrm{pcs}$ \\
\hline Valley bed consolidated & $2 \mathrm{pcs}$ \\
\hline Waterways & $6,4 \mathrm{~km}$ \\
\hline Exhaust ducts & $0,3 \mathrm{~km}$ \\
\hline Reprofilling the valley & $10634 \mathrm{~m}{ }^{3}$ \\
\hline Drains & $5,1 \mathrm{~km}$ \\
\hline Absorbent drains & $1,3 \mathrm{~km}$ \\
\hline Tailpipes & $41 \mathrm{pcs}$ \\
\hline Springs catchment & $5 \mathrm{pcs}$ \\
\hline Transversal work-thresholds & $3 \mathrm{pcs}$ \\
\hline Plantations (buckthorn and acacia) & $5,4 \mathrm{ha}$ \\
\hline & \\
\hline Land reclamation works & Measurement units \\
\hline Desilting on portions & $3726 \mathrm{~m}$ \\
\hline Waterways and flow bridges & $1200 \mathrm{~m}^{3}$ \\
\hline Prefabricated bridges & $1 \mathrm{pcs}$ \\
\hline Absorbent drains & $2.3 \mathrm{~km}$ \\
\hline
\end{tabular}

The results from archive show that the total value of the work was 1,1 million RON. All hydro-technical constructions and installations, land improvements through which, the surface water regime has been corrected and from the inside of the soil in the Nadas sub-basin have been over time the improvements of the basic conditions for the cultivation and development of agricultural crops. In this way the areas used for agriculture have expanded and there has been a lasting improvement in agricultural soil. Through the executed works were prevented, harmful phenomenons to agricultural land and it was possible to achieve advanced agriculture.

The soil in most areas, has an unstable water content and the work done to combat excess humidity and floods, obtaining of new land and the extension of arable land existing within the hydrographic sub-basin. Today, most of the agricultural land is divided in small plots and exploited by individual owners. In the last
60 years for agriculture there have been periods in which agricultural lands have been grouped in large areas of hundreds or even thousands of hectares and worked with heavy mechanical and high productivity machinery.

Fighting the destructive effects of floods could be done by building the check-dams and arranging water courses in the Nadas sub-basin, most of the major land reclamation works in our country being done more than 30 years ago (Dîrja and Budiu 2006).

From the research, resulted in the fact that in the last thirty years there were no other new land reclamation works, than those presented in the research, due to the lack of financial resources being executed only activities for maintenance of the already existing works. (http://www.anif.ro). The lack of land reclamation works in the study area was easy to observe through soil erosion in some areas and the impossibility of being used for agricultural crops. 


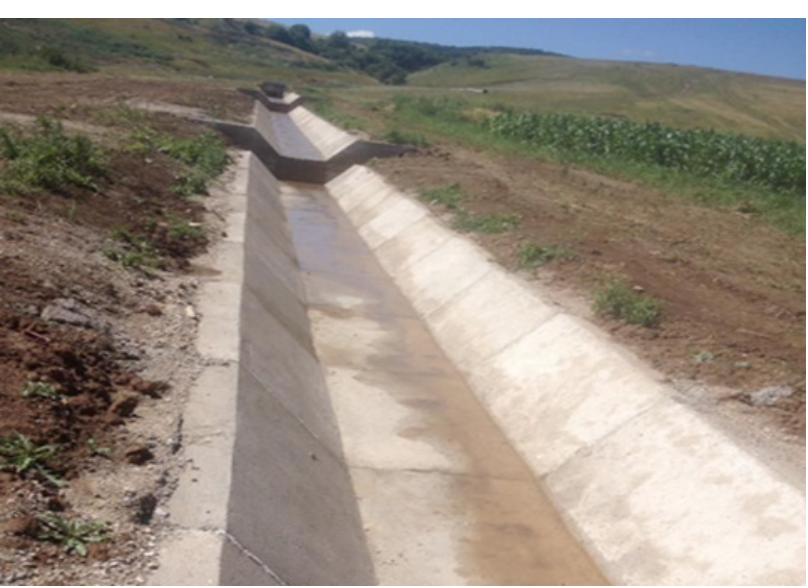

a) Waterways and flow bridges

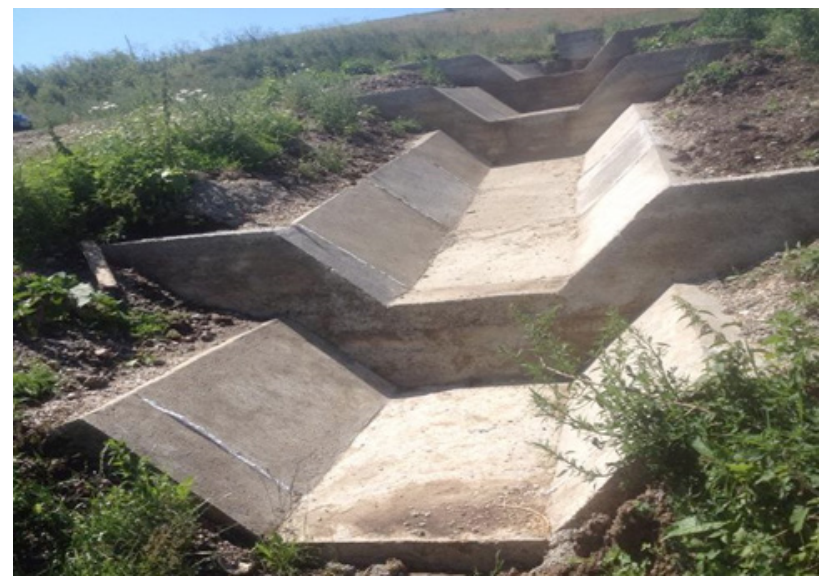

c) Waterways and drainage surface

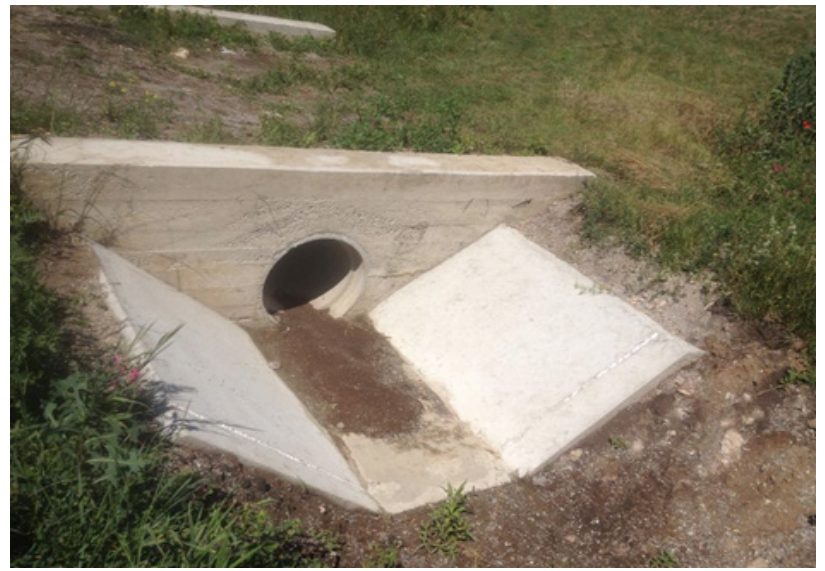

b) Prefabricated tubular bridges

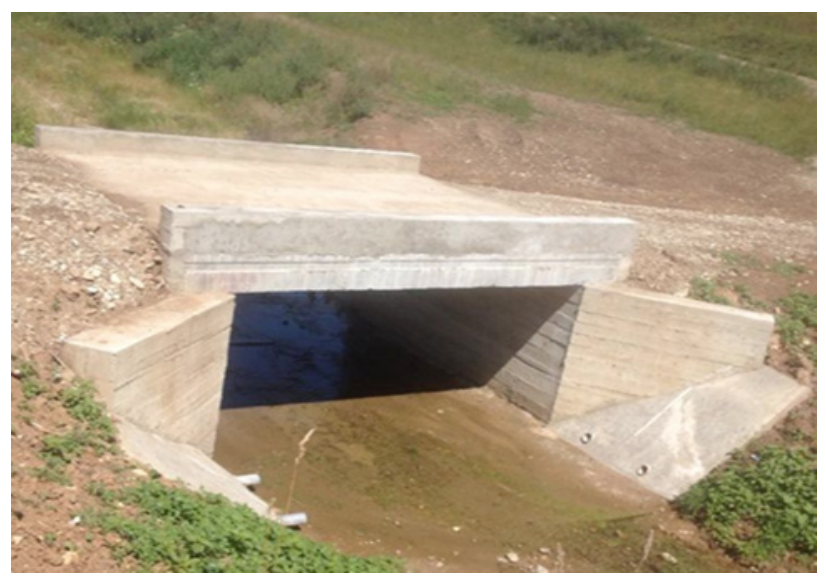

d) Road bridge of concrete

Figure 3. Presentation of some segments (a, b, c, d) of the executed works, from 2014, in the Macau-Inuc

The Figure 3 through images a, b, c, d below, displays the correct way of arranging the watercourses through important consolidation works that have been executed in 2014. Through removing water from swampy fields and combating gully erosion phenomenons, have returned to the agricultural use, significant areas of arable land (Sava and Wehry, 1967).

Land reclamation works applied on agricultural land, along with other agropedo-ameliorative measures, in the hydrographic sub-basin from the studied area have been over the years measures that have helped to remove the negative consequences on agriculture. Excess of humidity manifested in different forms had a particular impact on soil fertility and hydro-ameliorative works have determined use of abandoned land. Observations on the work requiring rehabilitation have brought a series of measures that can be proposed to improve agricultural production by combating excess moisture and drought.
Regularization runoff on slopes and prevent landslides, trough land reclamation works in the Someş Mic Hydrographic Basin, Inuc Valley sub-basin, Cluj County, have rehabilitated and protected for the next years an area of 450 hectares agricultural land. In order to achieve project of land reclamation have contributed the County Office for Rural Investment Financing (OJFIR) Cluj, and the Agency for Payments and Intervention for Agriculture (APIA) Cluj.

\section{Conclusion}

From the present research results the importance of hydro-amelioration works applied in a small hydrographic sub-basin, as well as the measures proposed for the rehabilitation of these works. In conclusion have been observed long periods of time without land reclamation works necessary for the agricultural production.

The lack of financial resources and human resources in the field of land reclamation leads 
to irreversible damage to the environment and also leads to higher investments when there is the possibility of building them.

The study highlighted the fact that in this small hydrographic sub-basin other important land reclamation works, as plantations, drainages, irrigations and prevention of soil erosion, are also needed in the next years.

From the present research resulted that thirty years ago there were many more land reclamation works as well as human resources specialized in the field but their number decreased and so resulted environmental damages year by year and also soil erosion.

\section{Refereces}

1. Constantin E, Maracineanu F (2005). Rolul imbunatatirilor funciare in dezvoltarea rurala durabila, Editura Cartea Universtara Bucuresti, (Capther 2).

2. Cowie A, Schneider UA, Montanarella L (2007). Potential synergies between existing multilateral environmental agreements in the implementation of land use, landuse change and forestryactivities.Doi.org/10.1016/j. envsci.2007.03.002.
3. Dîrja M, Sălăgean T, Matei F (2011). Tracking the behaviour of the torrential works on the valleys of the upper basin of the Someșul Mic River, Bulletin of University of Agricultural Sciences and Veterinary Medicine ClujNapoca, Horticulture 68 (2).

4. Dîrja M, Sălăgean T (2015). Îmbunătățiri funciare, Editura AcademicPres, Cluj-Napoca pp. 84-109.

5. Dîrja M, Budiu V (2006). Îmbunătățiri funciare. Combaterea excesului de umiditate pe terenurile agricole, Ed. AcademicPres, Cluj-Napoca (Chapter 2).

6. Lindsay C, Stringer S, Scrieciu S, Reed MS (2009). Biodiversity, land degradation, and climate change: Participatory planning in Romania.Doiorg/10.1016/j. apgeog.2008.07.008

7. Rus MI (2015). Bazinul Almașului, Studiu de geomorfologie aplicată, Editura Risoprint, Cluj-Napoca (Chapter 3).

8. Sava I, Wehry A (1967). Hidroamelioratii, Editura Didactica si Pedagogica, Bucuresti, (Chaper 3).

9. Land development to combat soil erosion (2017) http:// www.anif.ro/patrimoniu/amenajari ces.htm/Accessed 10.04.17

10. Rural_development(2017)https://portal.afir.info/ informatii_generale_pndr_pndr_2007_2013_dezvoltare_ rurala_feadr/ Accessed 12.08.17 